\section{Yield of Cucumber Infected with Pythium aphanidermatum when Grown with Soluble Silicon}

\author{
M. Chérif \\ Département de Phytologie, Faculté des Sciences de l'Agriculture et de \\ l'Alimentation, Université Laval, Québec, Qc G1K 7P4, Canada
}

J.G. Menzies, D.L. Ehret, and C. Bogdanoff

Agriculture Canada Research Station, P.O. Box 1000, Agassiz, B.C. VOM 1A0, Canada

\author{
R.R. Bélanger ${ }^{1}$ \\ Département de Phytologie, Faculté des Sciences de l'Agriculture et de \\ l'Alimentation, Université Laval, Québec, Qc G1K 7P4, Canada
}

Additional index words. Cucumis sativus, disease management

\begin{abstract}
Two experiments were conducted in separate locations, one at Université Laval in eastern Canada (Québec) and one at the Agassiz Research Station in western Canada (British Columbia), in an attempt to determine the effectiveness of soluble silicon (Si) against cucumber root disease caused by Pythium aphanidermatum Edson. Long English cucumber (Cucumis sativus $\mathbf{L}$. cv. Corona) plants were grown either in a standard nutrient solution or in nutrient solutions supplemented with $1.7 \mathrm{~mm}(100 \mathrm{ppm}) \mathrm{Si}$ and inoculated or not with the pathogen. Supplying the solutions with $1.7 \mathrm{~mm}$ Si significantly reduced mortality and disease symptoms attributed to infection by $P$. aphanidermatum. Grown in presence of $\mathrm{Si}$, plants infected with $P$. aphanidermatum showed a significant increase in yield, marketable fruit, and plant dry weight compared to Si-nonamended and infected plants. These beneficial effects were observed under both experimental conditions. The fruit yield of noninoculated plants was not affected by the presence of $\mathrm{Si}$ in the Agassiz experiment. However, Si-amended control plants were more productive in the experiment conducted at Laval, apparently because of contamination problems, which indicates that Si beneficial effects are most likely related to disease management.
\end{abstract}

Root diseases, caused by agents such as Pythium spp., are a particularly acute problem in recirculating nutrient systems because these systems offer an ideal environment for root pathogens to infect and spread (Gold and Stanghellini, 1985). Recently, Chérif and Bélanger (1992) have shown that amendment of the nutrient solution with soluble Si could prevent and reduce losses attributable to $P$. ultimum Trow on long English cucumber. Pythium aphanidermatum (Edson) Fitzp., the predominant species on cucumber cultures (Favrin et al., 1988), can spread rapidly by means of zoospores and has been reported to be extremely virulent under hydroponic conditions, potentially destroying a crop within days. In this context, it was pertinent to evalu-

Received for publication 12 Oct. 1993. Accepted for publication 28 Jan. 1994. Paper no. CRH-96 from Le Centre de Recherche en Horticulture and Agassiz Research Station contribution no. 501. We thank R. Daigle, T. Helmer, and C. Koch for their help and technical assistance. This work was supported by a grant from the program entente auxiliaire CanadaQuébec sur le développement alimentaire, and the Canada-British Columbia Environmental Sustainability Initiative. The cost of publishing this paper was defrayed in part by the payment of page charges. Under postal regulations, this paper therefore must be hereby marked advertisement solely to indicate this fact.

${ }^{1}$ To whom reprint requests should be addressed. ate the potential of soluble $\mathrm{Si}$ amendments against $P$. aphanidermatum on long English cucumber. To address this objective, collaborative experiments between Université Laval in eastern Canada (Québec) and Agassiz Research Station in western Canada (British Columbia) were conducted where the effects of a Si treatment could be evaluated under different growing conditions.

\section{Materials and Methods}

At both locations, the long English cucumber cultivar Corona was used. Seeds were sown in either cubes of rockwool (Grodan, Roermond, Holland) or in LC-1 Horticubes (Smithes-Oasis, Kent, Ohio) and fertilized daily with a $7 \mathrm{~N}-11 \mathrm{P}-27 \mathrm{~K}$ nutrient solution for 3 to 4 weeks under greenhouse conditions. After transplanting into hydroponic systems, the plants were grown in a base nutrient solution that contained (in mM) $13.0 \mathrm{NO}_{3}, 1.5 \mathrm{H}_{2} \mathrm{PO}_{4}$, 7.0 K, 3.5 Ca, $1.0 \mathrm{Mg}$, and $1.0-1.5 \mathrm{SO}_{4}$ and (in нм) $18.8 \mathrm{Fe}, 5.5 \mathrm{Mn}, 0.9 \mathrm{Zn}, 0.2 \mathrm{Cu}, 18.1 \mathrm{~B}$, and 1.0 Mo. Soluble Si was fed to the plants by amending the nutrient solution with $1.7 \mathrm{~mm}$ (100 ppm) Si in the form of potassium silicate (Kasil no. 6, 23.6\% $\mathrm{SiO}_{2}$; PQ Corp., Toronto, Ont.) for the duration of the experiment. Proper adjustments were made to the nutrient solutions to compensate for the additional input of $\mathrm{K}$. The nutrient solutions were prepared with tap water $(<0.05 \mathrm{~mm} \mathrm{Si})$, and final $\mathrm{pH}$ was adjusted to 5.8 with nitric acid. The $\mathrm{pH}$ and the electrical conductivity (EC) were continually monitored. The air was maintained between 17 and $27 \mathrm{C}$.

Inoculum was prepared from one isolate of $P$. aphanidermatum, isolated by $\mathrm{J}$. Menzies from greenhouse-grown cucumber, which was grown on potato dextrose agar (PDA) on 9-cm petri dishes for 5 days. For each 100 liters of nutrient solution to be inoculated, the equivalent of one petri dish culture was blended in $100 \mathrm{ml}$ of distilled water and added directly into the appropriate tank. Sterile PDA was used for the controls.

The first experiment was undertaken at Agassiz Research Station, Agriculture Canada, where 12 recirculating systems were built in a greenhouse. The greenhouse was divided into three blocks. Half of the recirculating systems were supplied with the standard nutrient solution ( $\mathrm{Si}-)$ and the other half with the Siamended solution $(\mathrm{Si}+)$. Five plants were transplanted into each system. Ten days later, pairs of $\mathrm{Si}+$ and $\mathrm{Si}-$ systems, within each of the three blocks, were inoculated with $P$. aphanidermatum. The two remaining nontreated $\mathrm{Si}+$ and $\mathrm{Si}-$ systems within each block were controls. Thus, the trial was comprised of four treatments: $P$. aphanidermatum inoculation with $(\mathrm{Si}+\mathrm{P}+)$ or without silicate amendments $(\mathrm{Si}-\mathrm{P}+)$ and two controls with $(\mathrm{Si}+\mathrm{P}-)$ and without silicate amendments ( $\mathrm{Si}-\mathrm{P}-)$.

The plants were trained to a wire $1.2 \mathrm{~m}$ above the trough using the "umbrella" system (Klieber et al., 1993), and one lateral was allowed to grow down from the top. Cucumber fruit growing below the sixth node were removed. Marketable fruit (weighing $250 \mathrm{~g}$ or more) were harvested three times per week and weighed. Then, at the final harvest, 7 weeks after transferring seedlings to the troughs, all fruit, marketable or not, were counted (number of fruit per plant). Each plant was then cut off at the crown, dried, and weighed. For plants that died before the final harvest, the date was noted and the above procedure was followed.

A second experiment was undertaken at Université Laval using the same hydroponic system as described by Chérif and Bélanger (1992). Plants were transferred to troughs in which the nutrient solution was pumped from 500-liter tanks and constantly circulated. The design was comprised of eight recirculating systems with each tank feeding two randomly selected troughs. Six plants, spaced at $0.75-\mathrm{m}$ intervals, were placed in each trough for a total of 96 plants for the experiment. A guard row was placed at each extremity of the experimental area. Each tank contained 300 liters of nutrient solution that was replaced every 3 weeks. The volume of the nutrient solution was maintained constant throughout the experiment by automatically adding tap water. Treatments were the same as in Expt. 1. The experiment was maintained for 10 weeks following the transfer of the seedlings to the troughs. The same cultural practices as in the previous experiment were used, and the same variables were measured throughout the ex- 
periment. In both experiments, weekly samples of the roots and the nutrient solutions were analyzed for Pythium propagules using a dilution plate technique with a Pythium-selective medium (PSM; Jeffers and Martin, 1986).

Data were analyzed by analysis of variance, and means were separated by Duncan's multiple range test $(P \leq 0.05)$. The software SuperANOVA (Abacus Concepts, Berkeley, Calif.) and SAS (SAS Institute, Cary, N.C.) were used for statistical analysis.

\section{Results and Discussion}

In both experiments, $P$. aphanidermatumtreated plants started showing typical symptoms of infection within 1 week after inoculation. For instance, in the experiment conducted at Université Laval (Fig. 1), Si-plants were rapidly affected by $P$. aphanidermatum, and only 10 days after inoculation, $50 \%$ of those plants $(\mathrm{Si}-\mathrm{P}+)$ were dead. In contrast, the $\mathrm{Si}+$ system reduced the impact of $P$. aphanidermatum infection by keeping close to $60 \%$ of the infected plants alive by the end of the experiment, while all $\mathrm{Si}-$ plants were dead (Fig. 1). Nonetheless, P. aphanidermatum induced important yield reductions when compared to controls. Average plant dry weight was reduced by $>50 \%$, and the same pattern of results held true for fruit set and marketable fruit at both locations (Table 1).

The $\mathrm{Si}+$ treatment consistently resulted in higher productivity for all variables measured 7 to 10 weeks after the plants were infected with $P$. aphanidermatum (Table 1). Within that treatment, a $\mathrm{Si}+$ amendment improved plant dry weight by $35 \%$, cucumber fruit set by $58 \%$, and the number of marketable fruit by $57 \%$ in the experiment conducted at Agassiz (Table 1). At Laval, the Si+ plants outyielded the $\mathrm{Si}-$ plants by $62 \%$ and $72 \%$ in terms of dry weight and fruit, respectively, and the $\mathrm{Si}$ amendment showed also a significant effect on the number of marketable fruit produced (Table 1). While the beneficial effects of soluble Si were believed to be confined to foliar patho-

Table 1. Average plant dry weight, number of fruit, and number of marketable fruit per plant of long English cucumber ('Corona') grown at the Agassiz Research Station (British Columbia) for 7 weeks or at Université Laval (Québec) for 10 weeks in a recirculating nutrient solution with or without potassium silicate and noninoculated or inoculated with Pythium aphanidermatum.

\begin{tabular}{lccc}
\hline \hline Treatment $^{\mathrm{z}}$ & $\begin{array}{c}\text { Plant dry wt } \\
(\mathrm{g})\end{array}$ & No. fruit/plant & $\begin{array}{c}\text { No. marketable } \\
\text { fruit/plant }\end{array}$ \\
\hline Agassiz $^{\mathrm{y}}$ & & & $4.1 \mathrm{c}$ \\
$\mathrm{Si}-\mathrm{P}-$ & $99.6 \mathrm{c}^{\mathrm{x}}$ & $8.7 \mathrm{c}$ & $4.7 \mathrm{c}$ \\
$\mathrm{Si}+\mathrm{P}-$ & $72.4 \mathrm{c}$ & $2.9 \mathrm{a}$ & $1.9 \mathrm{a}$ \\
$\mathrm{Si}-\mathrm{P}+$ & $31.5 \mathrm{a}$ & $4.4 \mathrm{~b}$ & $2.7 \mathrm{~b}$ \\
$\mathrm{Si}+\mathrm{P}+$ & $39.2 \mathrm{~b}$ & & $2.8 \mathrm{~b}$ \\
$\mathrm{Laval}{ }^{\mathrm{w}}$ & & $7.5 \mathrm{~b}$ & $5.0 \mathrm{c}$ \\
$\mathrm{Si}-\mathrm{P}-$ & $136.7 \mathrm{~b}$ & $15.8 \mathrm{c}$ & $0.8 \mathrm{a}$ \\
$\mathrm{Si}+\mathrm{P}-$ & $2.6 \mathrm{a}$ & $2.7 \mathrm{~b}$ \\
$\mathrm{Si}-\mathrm{P}+$ & $257.1 \mathrm{c}$ & $6.9 \mathrm{~b}$ & $\mathrm{c}$ \\
$\mathrm{Si}+\mathrm{P}+$ & $69.6 \mathrm{a}$ & $119.5 \mathrm{~b}$ &
\end{tabular}

${ }^{{ }^{2}} \mathrm{Si}-=0$ and $\mathrm{Si}+=1.7 \mathrm{~mm} ; \mathrm{P}-=$ noninoculated and $\mathrm{P}+=$ inoculated.

${ }^{\mathrm{y}}$ Each treatment represents an average of 15 plants.

xMean separation in columns for a given location by Duncan's multiple range test $(P \leq 0.05)$.

wEach treatment represents an average of 24 plants.

gens such as powdery mildews (Menzies et al., 1991), recent studies have shown that soluble Si can also be effective at repressing the root pathogen P. ultimum (Chérif and Bélanger, 1992), and this study constitutes the first report that $\mathrm{Si}$ is effective against the important and more destructive species $P$. aphanidermatum.

Interestingly, for control plants (not inoculated with $P$. aphanidermatum), the $\mathrm{Si}+$ and $\mathrm{Si}-$ treatments resulted in similar levels of productivity of all variables measured at Agassiz (Table 1). Similar results were obtained in an earlier study (Chérif and Bélanger, 1992). However, the presence of $\mathrm{Si}$ increased the yield of noninoculated plants $(\mathrm{Si}+\mathrm{P}-)$ compared to $\mathrm{Si}-\mathrm{P}-$ plants (Table 1) in the Laval experiment. In this experiment, control plants treated with $1.7 \mathrm{~mm} \mathrm{Si}$ gave a significantly higher dry weight and number of fruit. However, sampling the nutrient solutions and roots revealed that both $\mathrm{Si}+$ and $\mathrm{Si}-$ systems had been contaminated with $P$. aphanidermatum, a phenomenon only too frequently encountered in hydroponic systems. These results indicate that the amendment of Si alone did not influence the productivity of the plants, which

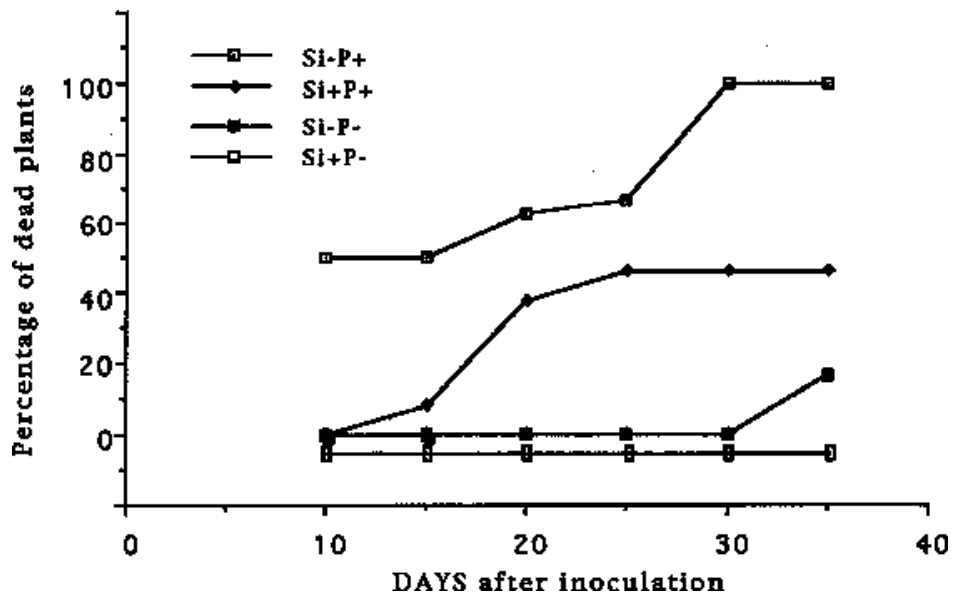

Fig. 1. Percent mortality over time of long English cucumber ('Corona') plants grown at Université Laval (Québec) for 10 weeks in a standard nutrient solution ( $\mathrm{Si}-$ ) or in a solution amended with $1.7 \mathrm{~mm}$ soluble $\mathrm{Si}(\mathrm{Si}+)$ and inoculated with $P$. aphanidermatum $(\mathrm{P}+)$ or sterile PDA (P-). is in line with the idea that the beneficial effect of $\mathrm{Si}$ is most likely related to better disease management. Nonetheless, this treatment should not be regarded as a miracle solution against pathogens, but as a prophylactic measure that can reduce and prevent losses against many pathogens and thus limit dependency on fungicides. Several other reports have associated the beneficial effects of $\mathrm{Si}$ with a decreased receptivity of some plants to fungal pathogens (Menzies et al., 1991). The exact mechanisms by which Si can provide protection against pathogens are still not fully understood, but there is accumulating evidence that induced resistance would play a major role (Chérif et al., 1992a, 1992b).

\section{Literature Cited}

Chérif, M. and R.R. Bélanger. 1992. Use of potassium silicate amendments in recirculating nutrient solutions to suppress Pythium ultimum on long English cucumber. Plant Dis. 76:10081011.

Chérif, M., N. Benhamou, J.G. Menzies, and R.R. Bélanger. 1992a. Silicon-induced resistance in cucumber plants against Pythium ultimum. Physiol. Mol. Plant Pathol. 41:411-425.

Chérif, M., J.G. Menzies, N. Benhamou, and R.R. Bélanger. 1992b. Studies of silicon distribution in wounded and Pythium ultimum-infected cucumber plants. Physiol. Mol. Plant Pathol. 41:371-385.

Favrin, R. J., J.E. Rahe, and B. Mauza. 1988. Pythium spp. associated with crown rot of cucumbers in British Columbia greenhouses. Plant Dis. 72:683-687.

Gold, S.E. and M.E. Stanghellini. 1985. Effects of temperature on pythium root rot of spinach grown under hydroponic conditions. Phytopathology 75:333-337.

Jeffers, S.N. and S.B. Martin. 1986. Comparison of two media selective for Phytophthora and Pythium species. Plant Dis. 70:1038-1043.

Klieber, A., W.C. Lin, P.A. Jolliffe, and J.W. Hall. 1993. Training systems affect canopy light exposure and shelf life of long English cucumber. J. Amer. Soc. Hort. Sci. 118:786-790.

Menzies, J.G., D.L. Ehret, A.D.M. Glass, and A.L. Samuels. 1991. The influence of silicon on cytological interactions between Sphaerotheca fuliginea and Cucumis sativus. Physiol. Mol. Plant Pathol. 39:403-414. 